\title{
A Review of Salty Waste Stream Management in the Australian Dairy Industry
}

\author{
G. Q. Chen ${ }^{1}$, S. Talebi ${ }^{1}$, S. L. Gras ${ }^{1,2}$, M. Weeks ${ }^{3}$, S. E. Kentish ${ }^{1 *}$ \\ ${ }^{1}$ The ARC Dairy Innovation Hub, Department of Chemical Engineering, The University of \\ Melbourne, Victoria 3010, Australia. \\ 2 The Bio21 Molecular Science and Biotechnology Institute, The University of Melbourne, \\ Victoria 3010, Australia \\ ${ }^{3}$ The Dairy Innovation Australia Ltd., Werribee, VIC 3030, Australia
}

\begin{abstract}
Saline wastewater is a by-product of cheese manufacturing and whey processing that can have serious environmental and economic consequences. Salty streams originating from dairy processing operations include chromatography wastes, clean-in-place wastewater, acid whey and waste generated from whey demineralisation processes such as nanofiltration, electrodialysis and ion exchange. With the participation of the major dairy companies in Australia, an industry wide survey was conducted to acquire a comprehensive understanding of the management strategies for these salty waste streams. High salinity waste streams are commonly directed to evaporation ponds. However, environmental impacts from land degradation, odour and dust have prevented the construction of further evaporation ponds in some areas of Australia. The survey results also show that disposal to municipal trade waste is not always effective, as the current levels of some salinityrelated parameters are significantly higher than the levels allowed by the local water/environmental authorities. For high salinity streams, salt removal can lead to more substantial savings in trade waste charges compared to wastewater volume reduction. Thus, salt removal and recovery from salty waste streams has become a major focus of the sustainability agenda of the Australian dairy industry.
\end{abstract}

Keywords: Dairy; Effluent; Salinity; brine

\author{
*Corresponding Author \\ Prof S. Kentish \\ Tel: +61 383446682 \\ Fax: +6138344 4153 \\ E-mail address: sandraek@unimelb.edu.au
}




\section{Introduction}

The \$13 billion Australian dairy industry is a major exporter and the third largest rural industry in Australia(Dairy Australia, 2016). As one of the major dairy exporters to the global dairy market (Farrell and Maginnis, 2016), the Australian dairy industry encounters challenges that are largely shared by dairy processors operating across the world. Saline wastewater management is one of these challenges. Similar to the environmental concerns arising from the brine generated from industries such as seawater desalination and mining, dairy salty wastewater in Australia is subject to increasingly strict regulatory requirements due to the increase in agricultural water usage and local land degradation caused by sodium leaching (Aral et al., 2007). The origins of the saline wastewater, the current management strategies adopted by the Australian dairy industry, and the unique characteristics of these streams must be understood if suitable mitigation strategies are to be developed. This is the focus of the present paper. Importantly, an industry survey was conducted to specifically gather information about salty wastewater from Australian dairy processors. The results of this survey provide a better understanding and guidance to future research in this area.

A summary of the sources of dairy processing waste in Australia and the current mechanisms for disposal is presented in Figure 1. This diagram represents how different waste streams can be treated in any given dairy processing facility. The generic feeds to a dairy plant are raw milk, minor ingredients, water, energy, cleaning chemicals, refrigerants and packaging materials regardless of the dairy product produced. The eventual discharge from the dairy processing boundary can be classified into three categories: wastewater, solid waste and air emissions. Wastewater is normally treated on-site or processed at a local municipal treatment station. Wastewater treated on site can be discharged for land application or again directed to the municipal sewer, depending upon the chemical characteristics and the nutrient level. Sludge generated from the onsite biological treatment and biosolids originating from wastewater separation processes (such as dissolved air flotation(Danalewich et al., 1998)) are usually dewatered before being disposed, together with other solid wastes. The dewatering flow is sent back to the water treatment process. 
In general, dairy processing effluents exhibit the following characteristics (Durham and Hourigan, 2009):

- High organic load caused by the milk components;

- Variation in $\mathrm{pH}$ due to the presence of the cleaning agents and the process chemicals;

- High levels of phosphorus and nitrogen;

- Fluctuations in temperature.

Liquid effluent from dairy processing facilities can include high salt effluent, process condensate, cooling tower blowdown and wash water, as shown in Figure 1. Process condensate is most likely treated separately and recycled back to the steam generation process. Wash water may contain tanker wash, milk spill, detergents and sanitisers. High salt effluent, which is the focus of this paper, is generated from a variety of sources, including whey processing, chromatographic separation and clean-in-place (CIP) processes. The volume and salinity of this wastewater is highest, however, in plants that produce hard and semi-hard cheese as their primary product. As a demand-driven and value-added product (Daufin et al., 2001), cheese production is forecast to continue to grow faster than any other dairy product in the foreseeable future, as illustrated in Figure 2. While Australia contributes to $\sim 2 \%$ of the global cheese production (Foreign Agricultural Service and United States Department of Agriculture (USDA), 2013), cheese making is ranked at the top of milk utilisation in Australia, with $\sim 30 \%$ of milk being processed to more than 340,000 tonnes of cheese (Dairy Australia, 2016). Every kilogram of cheese produced creates 9 litres of whey. When whey is further processed to various products, salts from the milk and the cheese-salting processes will be concentrated in the waste streams. Previous studies have shown(Aral and Sleigh, 2007; Aral et al., 2007) that over 6.7 billion litres of milk were processed in Victoria, Australia in 2007. A total of 24 factories in Victoria discharged 10 billion litres of wastewater (an average waste volume coefficient of around $1.55 \mathrm{~L} / \mathrm{L}$ milk processed) and 3,400 tonnes of sodium in a single year. In addition, over \$20 million was spent on managing milk processing related waste. 
Due to the high organic load and salinity, management strategies for these waste streams have focused on safe disposal (Trebler et al., 1938) and value-added product recovery. Over the last few decades a variety of technologies have been developed and commercialised for dairy by-product utilisation and wastewater treatment. Increasingly strict regulatory requirements have been imposed by the local environmental and water authorities, however, due to the increase in agricultural water usage and the degradation of local land. As a result, the wastewater management philosophy in the Australian dairy industry is shifting from 'treat or pay' towards 'treat or close'. 


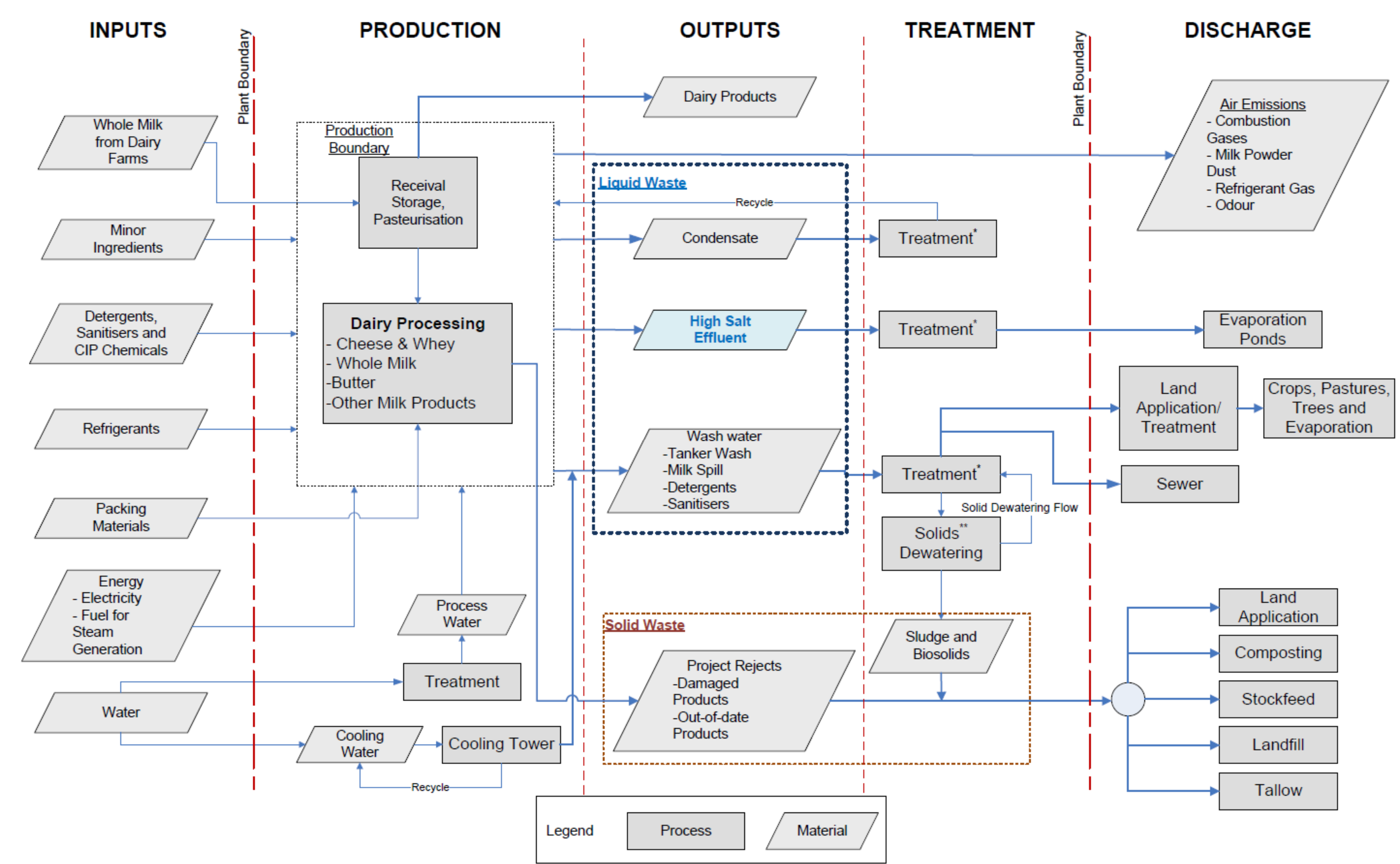

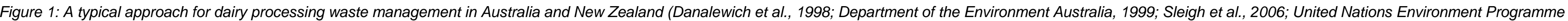

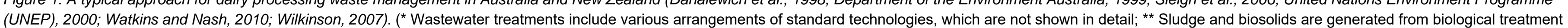
and wastewater separation processes (such as Dissolved Air Flotation.) 


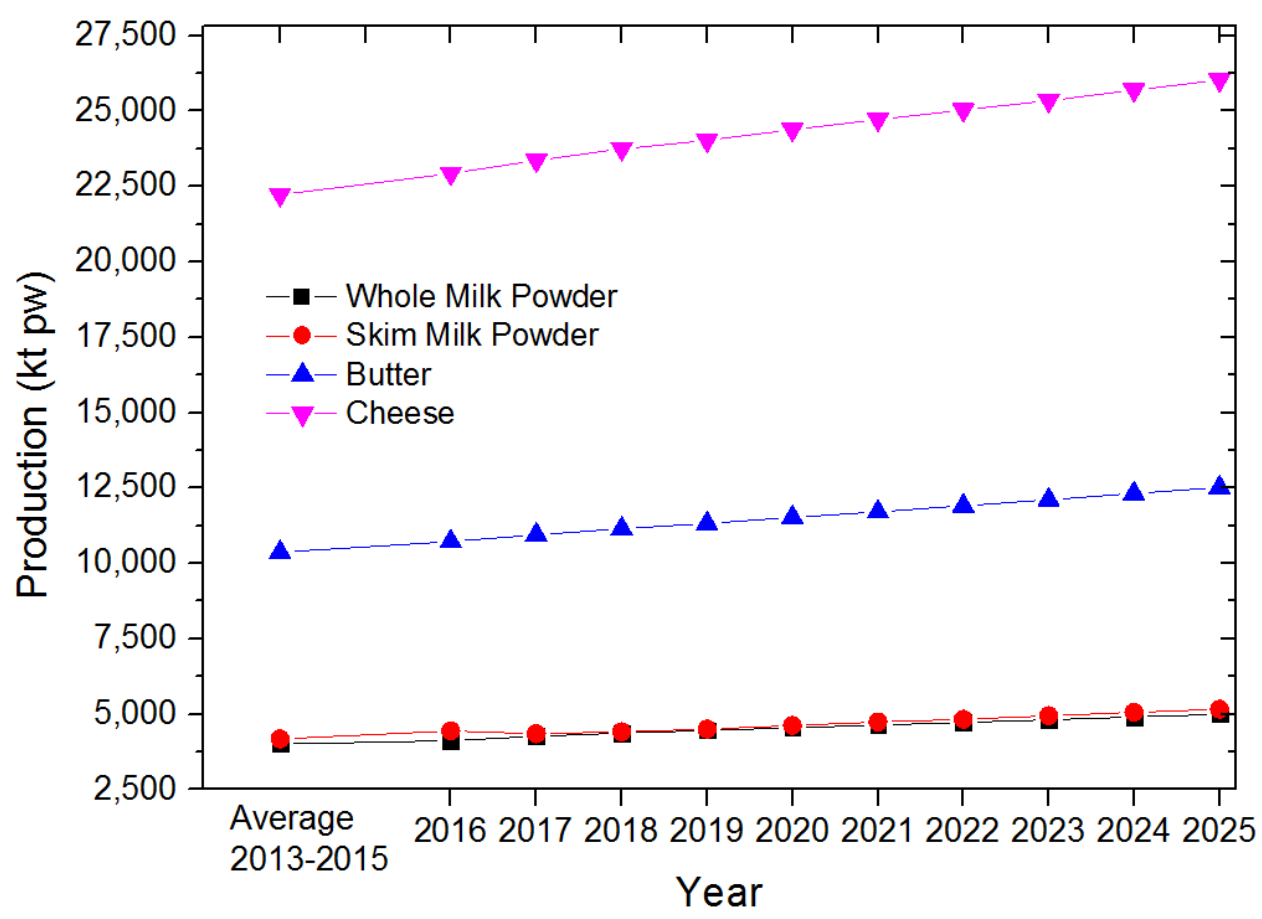

Figure 2: World dairy projections (2016-2025). Data from the Organisation for Economic Co-operation and Development (OECD 2016). (kt pw: kilotonne per week)

\section{Australian dairy industry survey}

A survey of salty waste stream management in the Australian dairy industry was conducted from June to October 2014, aiming to identify the current issues and challenges in terms of managing salty wastewater to comply with environmental regulations. The survey focused on salty liquid waste management practices across 11 Australian dairy factories located in Victoria, South Australia, New South Wales and Tasmania. Together, these factories process more than 3 billion litres of milk annually and generate more than 7 billion litres of wastewater per annum. A wide range of dairy products are produced, including (hard and soft) cheese, whey powder, whey protein concentrate, demineralised whey powder, skim milk powder, creams and ice cream. In particular, this survey assessed the milk consumption volume, product mix, chemicals used, wastewater generation, current wastewater treatment practices and perceived salty waste problems. The survey was conducted by in-person or telephone interviews of relevant operational personnel, with followup emails providing additional information. 
The amount of wastewater generated per quantity of milk processed is often called the 'waste volume coefficient'. In the 1970s, the minimum and maximum waste volume coefficients for the dairy industry in general, and for cheese production plants in particular, were estimated by Harper et al. (Harper et al., 1972) to be 2.76 and $3.56 \mathrm{~L} / \mathrm{L}$ milk processed, respectively (see Table S1). In 1998, Danalewich et al.(Danalewich et al., 1998) conducted a survey of 14 cheese producers in the Midwestern states of the United States and estimated the waste volume coefficients had significantly reduced, with a mean of $1.43 \mathrm{~L} / \mathrm{L}$, varying between 0.35 and $2.60 \mathrm{~L} / \mathrm{L}$. The reduction in the waste volume coefficient was believed to be caused by increases in plant size, process automation over the years and the use of CIP recovery systems.

The most recent survey in Australia prior to the present survey was conducted over ten years prior in the Closing the Loop (CTL) Project in 2003 (Wilkinson et al., 2004), which measured a mean waste volume coefficient of $1.55 \mathrm{~L} / \mathrm{L}$. The current survey (Case 11 in Table S1), shows that 1.8 (mean) litres of wastewater is generated for each litre of milk processed. This is in the same order of magnitude as the studies conducted over the past two decades. This mean waste volume coefficient is slightly higher than a USA study in 1998 and the CTL project in 2003, probably due to the wider product mix represented in the current study.

It should be noted that wastewater flowrates are extremely difficult to predict although detailed process data can be obtained. Both Harper et al.(Harper et al., 1972) and Danalewich et al.(Danalewich et al., 1998) concluded that management planning and strategies determine the volume of wastewater generation. However, the characteristics of waste stream are important to wastewater treatment evaluation and strategy development. The current survey shows that the wastewater leaving the factory site is between $15^{\circ} \mathrm{C}$ and $40{ }^{\circ} \mathrm{C}$ (mean: $30^{\circ} \mathrm{C}$ ), $4-12$ in $\mathrm{pH}$ and $1,500 \mu \mathrm{S} / \mathrm{cm}$ to 9,500 $\mu \mathrm{S} / \mathrm{cm}$ (mean $3,000 \mu \mathrm{S} / \mathrm{cm}$ ) in conductivity. All parameters reported in the survey are within the expected ranges of general wastewater characteristics, as shown in Tables S1 and S2. 
The key issues and challenges identified during the survey in handling the high salinity waste streams for theses dairy processing facilities are:

- The volume of wastewater being discharged;

- Power supply limitations at the existing plants, meaning that the addition of extra energy intensive unit operations/processes is restricted;

- Meeting the increasing regulatory requirements imposed by the local environmental or water authorities.

Survey results indicated that onsite generation of high salinity waste streams can adversely affect the salinity of the final ex-plant effluent if the volume is significant. Overall, the volume ratio of low to high salinity wastewater is about 8 . Around $25 \%$ of the dairy processing facilities dispose the high salinity streams to evaporation ponds rather than mixing these streams with the general wastewater. In contrast, $75 \%$ of the surveyed dairy plants generally mix the high salinity streams with low salinity plant effluent and discharge as trade wastewater or for land irrigation, after a number of treatment processes. In these cases, however, the levels of some water purity parameters (Table 1) can be significantly greater than those specified by water authorities for trade wastewater, especially for sodium content and conductivity. In addition, it is noted that in these cases the volume of salty waste is not reduced. 
Table 1: Maximum levels of some water purity parameters for the effluent from dairy processing facilities surveyed in the current study. Also shown are the corresponding limits published as trade wastewater criteria for a range of relevant water authorities. The most stringent acceptance criterion is shown.

\begin{tabular}{c|c|c|c}
\hline Characteristics & Unit & $\begin{array}{c}\text { Maximum Current } \\
\text { Level }\end{array}$ & $\begin{array}{c}\text { Most Stringent } \\
\text { Acceptance Criterion } \\
\text { (Goulburn Valley } \\
\text { Region Water } \\
\text { Corporation, 2012; } \\
\text { South Gippsland } \\
\text { Water, 2013; Western } \\
\text { Water, 2011; Yarra } \\
\text { Valley Water Victoria } \\
\text { Australia, 2014) }\end{array}$ \\
\hline pemperature & ${ }^{\circ} \mathrm{C}$ & $15-40$ & $6-10$ \\
\hline Nutrient level (P) & $\mathrm{mg} / \mathrm{L}$ & $>45$ & $<38$ \\
\hline BOD & $\mathrm{mg} / \mathrm{L}$ & $>900$ & $<10$ \\
\hline Sodium & $\mathrm{mg} / \mathrm{L}$ & $>600$ & $<400$ \\
\hline Sulphate & $\mathrm{mg} / \mathrm{L}$ & $>600$ & $<200$ \\
\hline Conductivity & $\mu \mathrm{s} / \mathrm{cm}$ & $>4,000$ & $<300$ \\
\hline TDS & $\mathrm{mg} / \mathrm{L}$ & $>1,800$ & $<1000$ \\
\hline
\end{tabular}

\section{Wastewater from in the dairy industry}

\subsection{Characterisation of dairy wastewater}

Publications on the physicochemical characterization of dairy wastewater are limited and often lack the identification of the origin of the waste streams in detail. Table 2 and Tables S1 and S2 (in the Supplementary Information) summarise the published data available, including that from the present survey, mainly involving the processes that manufacture cheese, within the production range. The data represents only the ranges of these characteristics, as the actual values fluctuate with time.

Despite the wide range of plants in these surveys, the average salinity and sodium load are very similar $(1,800-2,700 \mathrm{mg} / \mathrm{L} \mathrm{TDS}, 532-600 \mathrm{mg} / \mathrm{L} \mathrm{Na})$. In general, the levels of biochemical oxygen demand (BOD) or chemical oxygen demand (COD), total nitrogen and phosphorous are quite significant for dairy effluents. Wastewater is often pre-treated onsite before discharging to the municipal water treatment 
facilities as trade waste. If some of the characteristics listed in Table 1 are not monitored and managed properly, however, disposal costs can increase significantly. The following sections will explore the different sources of salty waste generated in a cheese manufacturing plant.

\subsection{Origins of salty waste streams}

Salty waste streams in the dairy industry are generally associated with cheese manufacturing, as well as whey processing and clean-in-place (CIP) operations. This is apparent from the wastewater salinity (indicated by TDS, conductivity and $\mathrm{Na}$ concentration) in Tables S1 and S2 (Supplementary Information). Figure 3 summarises a typical cheese making process and the possible sources for salty waste.

Salt is added to the protein-rich cheese curd to reduce the water activity within the curd when making semi-hard or hard cheese such as Cheddar or Colby. Approximately $35-50 \%$ of the added salt is retained in the curd. The excessive moisture is expelled from the curd during salting and pressing processes, together with a significant amount of the added salt, thus forming salty whey. Table S3 shows the compositions of sweet whey, salty whey and acid whey that are generated from different cheese sources. It is apparent that the ash (mineral) content in salty whey is up to ten times higher than that in sweet whey and acid whey. Salty whey cannot be discharged directly to the sewer, thus complicating its processing and potential applications.

In addition to the salty whey generated during cheese manufacturing, whey demineralization also generates salty waste streams. Whey demineralization is necessary, as whey usually contains $8-12 \%$ minerals on a dry weight basis(Gernigon et al., 2011), which can limit the utilization of whey as a food ingredient(Bylund and Hellman, 2015) and introduce problems in downstream processes, such as spray driers, for whey powder manufacturing (Gernigon et al., 2011). Thus whey demineralization increases product value and its application, for example, partially demineralized whey (25-30 \%) can be used in ice-cream and bakery products, while highly demineralized whey (90-95\%) can be applied 
in infant formula. Importantly, mineral concentration must be reduced before lactose crystallisation to ensure a high level of yield and purity. Depending on the degree of desalination required, nanofiltration (or 'leaky reverse osmosis'), electrodialysis and ion exchange can be employed. Each of these processes is considered here in turn.

\subsubsection{Salty whey NF permeate}

Nanofiltration (NF) systems are capable of partially removing monovalent ions and organic compounds with a molecular weight less than $300 \mathrm{Da}$, producing a retentate concentrated in multivalent salts and higher molecular weight organic compounds (Kumar et al., 2013). There are many advantages associated with the use of NF for whey demineralization compared to electrodialysis and ion-exchange. These include: (1) low capital and operating costs; (2) simple installation and operation; (3) elimination of regeneration chemicals (Okawa et al., 2015); (4) generation of small effluent volumes with low BOD (Gernigon et al., 2011). NF can only achieve partial demineralization, however, up to $30 \%$, compared to other processes (Bylund and Hellman, 2015).

As illustrated in Figure 3, NF is used as the first step in salty whey processing to achieve a retentate stream where the protein to salt ratio resembles natural sweet whey. This stream is then fed to the ordinary whey processing operations. The NF permeate produced is a brine stream that, although of lowered volume, needs to be discharged as a salty waste stream to the evaporation ponds. NF membranes are also utilized for partial demineralization of sweet whey, where the process generates a less concentrated brine stream than the salty whey NF permeate achieved with full demineralisation.

\subsubsection{Spent electrodialysis brine}

Electrodialysis (ED) relies on the transport of ions through ion exchange membranes by means of a direct current (DC) voltage for demineralisation. The degree of demineralization is determined by ash content, residence time, current density and flow viscosity (Gernigon et al., 2011). Compared to ion exchange (IE), this approach is found to be cost-effective only for demineralization levels below $70 \%$ 
(Bylund and Hellman, 2015). When further comparing ED and IE processes, it is found that ED has a lower cumulative energy consumption and generate less waste water(Greiter et al., 2002). On the other hand, the replacement cost of the equipment, especially membranes, spacers and electrodes is relatively high and contributes up to $35-40 \%$ of the operating cost of the process (Bylund and Hellman, 2015; Gernigon et al., 2011).

During whey processing, ED is used for further demineralization of NF retentate before the evaporation and drying process. The system requires a brine solution to 'collect' the removed salts. This concentrated brine stream adds to the total effluent salt load.

\subsubsection{Spent ion exchange brine}

Ion exchange (IE) refers to the process in which whey is passed through a fixed-bed column loaded with polymeric beads that contain fixed charge groups that attract and bind the ions in the solution. After a period of time, the beads become saturated and a regeneration step is required to release the adsorbed ions. This regeneration step generally involves the use of acids, alkalis or a brine solution, which again adds to the salty effluent load of the facility. As shown in Table 3, the salinity of spent ion exchange brine is typically half that of salty whey (TDS 23,800 compared to $47,930 \mathrm{mg} / \mathrm{L}$ ) but with a considerably lower COD.

IE is used widely in the dairy industry not only for whey demineralisation but also for decalcification of whey and permeates, as well as boiler feed water softening. Ion exchange is reported to be able to achieve up to 95\% mineral removal if a suitable type of resin is applied (Bylund and Hellman, 2015; Greiter et al., 2002; Pesta et al., 2007). Each polymeric bead can only adsorb a certain number of ions, however, and the bed size consequently increases linearly with the salt concentration of the feed. Further, when run as a continuous process at least two beds are required to allow for one being in the regeneration cycle. The resulting capital costs mean that ion-exchange is most suited to low salt feed 
solutions. Operating costs can also be high due to the high consumption of rinse water and chemicals during resin regeneration(Kumar et al., 2013) (Gernigon et al., 2011).

\subsubsection{Chromatography waste}

Chromatography is similar to ion exchange but proteins bind to the fixed absorption sites of the polymeric beads, rather than ions. This approach is often used for isolating specific whey proteins such as lactoferrin, lactoperoxidase, $\alpha$-lactalbumin and $\beta$.-lactoglobulin (de Wit, 2001). By controlling the $\mathrm{pH}$ of the whey stream, the protein net charge and the binding capacity of the absorbent, specific proteins can be selected to bind to the beads. Elution of the bound proteins from the beads requires salt solutions of increasing concentration. Each eluate is further processed and purified by ultrafiltration (UF) and diafiltration (DF) to produce a protein of about $95 \%$ purity. The permeate streams from the UF and DF processes contain salts from the original salt solution used for elution and the additional salts and organic content from the whey stream. These streams must be treated to remove the organic content before being reused for the elution step.

\subsubsection{Mother liquor}

The process of manufacturing lactose begins with concentrating whey UF permeate to $60 \%$ solids in a multiple effect evaporator. Lactose is crystallized from the concentrate and separated, resulting a mother liquor containing $20-30 \%$ of the lactose and $90 \%$ of the ash (Durham and Hourigan, 2009). Because it is perishable and high in BOD and salinity, the mother liquor has limited use as a stockfeed or fertiliser. 


\subsubsection{Clean-in-Place (CIP) wastewater}

Dairy processing operations rely heavily upon CIP because of the high levels of cleanliness and hygiene required. CIP is a method of cleaning and sanitising the interior surfaces of pipes, vessels, equipment, filters and fittings without taking them apart. CIP operations consume a considerable amount of process water and are responsible for $50-95 \%$ of the overall volume of generated waste streams(Durham and Hourigan, 2009). The cleaning cycle involves water rinse steps, caustic wash steps to remove organic deposits, acidic wash steps to remove mineral soils and sanitising steps (Henck, 1995). The current survey indicated that chemicals used in the dairy plants that are included in the salty waste water include sodium chloride $(\mathrm{NaCl})$, sodium hydroxide $(\mathrm{NaOH})$, sodium hypochlorite $(\mathrm{NaOCl})$, nitric acid $\left(\mathrm{HNO}_{3}\right)$, sulphuric acid $\left(\mathrm{H}_{2} \mathrm{SO}_{4}\right)$, phosphoric acid $\left(\mathrm{H}_{3} \mathrm{PO}_{4}\right)$, potassium hydroxide $(\mathrm{KOH})$, hydrochloric acid $(\mathrm{HCl})$ and peracetic acid $\left(\mathrm{CH}_{3} \mathrm{CO}_{3} \mathrm{H}\right)$.

Both alkaline solutions (generally caustic soda) and acidic solutions (a mixture of nitric and phosphoric acids) can be used multiple times in some CIP operations but are ultimately discharged to the wastewater treatment facility, increasing the salt load (Table 3). A combination of membrane technologies, such as microfiltration, ultrafiltration and nanofiltration, have proved effective for cleaning solution regeneration, which allows these solutions to be recycled a greater number of times, thus providing a reduction in energy consumption, water and chemical usage (Daufin et al., 2001; Eide et al., 2003; Merin et al., 2002; Räsänen et al., 2002). There is a trade-off, however, between the payback period of implementing such a recovery system and the rate of waste disposal at a particular site. Recovery systems that claim to have a shorter payback period always depend upon initially high rates of waste disposal for single use CIP solutions (Dresch et al., 2001; Durham and Hourigan, 2009; Henck, 1995). Our survey indicated that only $30 \%$ of Australian facilities have implemented CIP recovery systems and $50 \%$ have adopted chemical minimisation strategies to recirculate and reuse CIP solution. Both are effective strategies for reducing the volume of saline wastewater discharged to trade waste. 


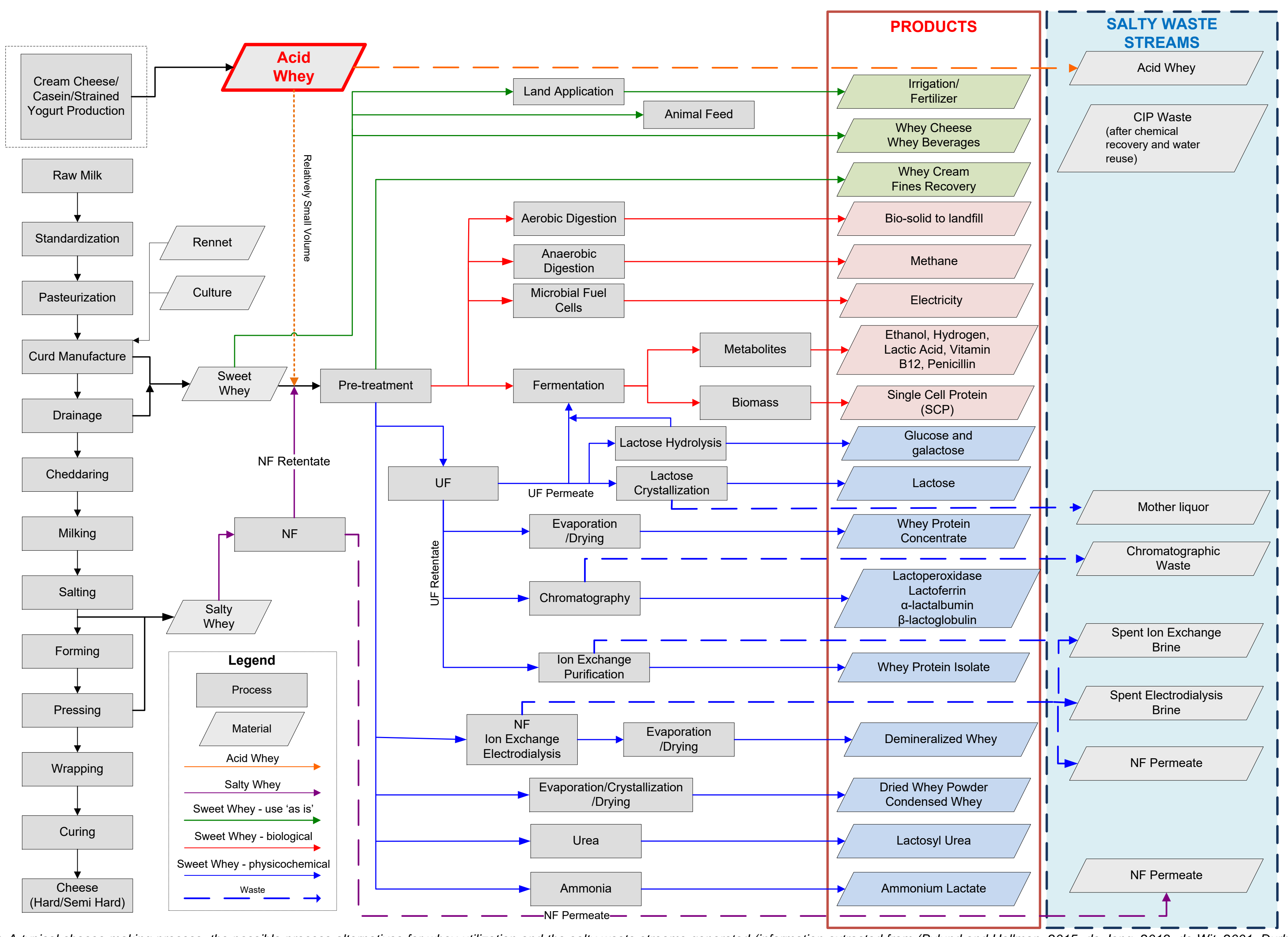

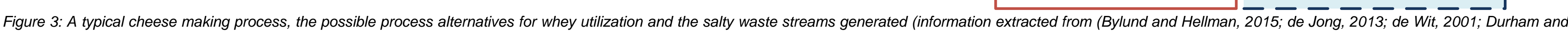
Hourigan, 2009; Pesta et al., 2007; Prazeres et al., 2012; Renner and Abd El-Salam, 1991; Siso, 1996; Venkatraman and Achi, 2004)). 
Table 2: Wastewater information on various types of dairy processing plant. Physical and chemical characteristics are presented in Tables S1 and S2.

\begin{tabular}{|c|c|c|c|c|c|}
\hline Case ID & Location & Year & Plant Type & Waste Type & Reference \\
\hline 1 & Upper Midwest, USA & 1998 & $\begin{array}{l}15 \text { plants, Primary product: mostly } \\
\text { hard/semi-hard cheese }\end{array}$ & Composite wastewater samples & $\begin{array}{c}\text { (Danalewich et al., } \\
\text { 1998) }\end{array}$ \\
\hline 2 & $\begin{array}{l}\text { CTL, Survey to Victorian } \\
\text { factories, Australia }\end{array}$ & 2003 & $\begin{array}{l}24 \text { production sites, products include } \\
\text { milk, cream, butter, cheese, powder, } \\
\text { ice cream, dairy dessert }\end{array}$ & Wastewater & $\begin{array}{l}\text { (Wilkinson et al., } \\
\text { 2004) }\end{array}$ \\
\hline 3 & $\begin{array}{l}\text { Dairy Farmers, } \\
\text { Toowoomba QLD, Australia }\end{array}$ & 2004 & $\begin{array}{l}\text { Mozzarella cheese, whey powder, } \\
\text { butter and vein cheese (18:3:8:0.08) }\end{array}$ & $\begin{array}{l}\text { A mixture of discarded whey and } \\
\text { wash water }\end{array}$ & $\begin{array}{l}\text { (Verheyen et al., } \\
\text { 2011) }\end{array}$ \\
\hline 4 & Banha, Kalubia, Egypt & 2008 & $\begin{array}{l}\text { Arab Dairy Factory (Cheese } \\
\text { manufacturing) }\end{array}$ & $\begin{array}{l}\text { End of pipe effluent, mix of dairy } \\
\text { and domestic water ( } 7 \text { to } 3 \text { ) }\end{array}$ & (Tawfik et al., 2008) \\
\hline 5 & $\begin{array}{l}\text { Murray Goulburn, } \\
\text { Leitchville VIC, Australia }\end{array}$ & 2008 & Cheese & Not-specified & $\begin{array}{l}\text { (Verheyen et al., } \\
\text { 2009) }\end{array}$ \\
\hline 6 & $\begin{array}{l}\text { Murray Goulburn, } \\
\text { Rochester VIC, Australia }\end{array}$ & 2008 & Cheese/milk powder & Effluent & $\begin{array}{c}\text { (Verheyen et al., } \\
\text { 2009) }\end{array}$ \\
\hline 7 & Victoria, Australia & 2004 & $\begin{array}{l}\text { Small-scale specialty farm cheese } \\
\text { manufacturers }\end{array}$ & Washdown wastewater & $\begin{array}{c}\text { (Venkatraman and } \\
\text { Achi, 2004) }\end{array}$ \\
\hline 8 & $\begin{array}{l}\text { Burra Foods, Korumburra } \\
\text { VIC Australia }\end{array}$ & 2008 & $\begin{array}{l}\text { Customized fresh and frozen dairy } \\
\text { ingredients }\end{array}$ & $\begin{array}{l}\text { Dirty stream - effluent before any } \\
\text { treatment }\end{array}$ & $\begin{array}{l}\text { (Verheyen et al., } \\
\text { 2009) }\end{array}$ \\
\hline 9 & $\begin{array}{l}\text { Burra Foods, Korumburra } \\
\text { VIC Australia }\end{array}$ & 2008 & $\begin{array}{l}\text { Customized fresh and frozen dairy } \\
\text { ingredients }\end{array}$ & $\begin{array}{l}\text { Effluent from the aerobic } \\
\text { bioreactor }\end{array}$ & $\begin{array}{l}\text { (Verheyen et al., } \\
\text { 2009) }\end{array}$ \\
\hline 10 & Minas Gerais, Brazil & 2013 & $\begin{array}{l}\text { UHT milk, yogurt, cheese, cottage } \\
\text { cheese and petit Suisse }\end{array}$ & $\begin{array}{l}\text { Post sieving and induced air } \\
\text { flotation (IAF) }\end{array}$ & $\begin{array}{l}\text { (Andrade et al., } \\
\text { 2014) }\end{array}$ \\
\hline 11 & $\begin{array}{l}\text { Dairy plants in Victoria, } \\
\text { New South Wales, South } \\
\text { Australia and Tasmania, } \\
\text { Australia }\end{array}$ & 2014 & $\begin{array}{l}\text { (hard and soft) cheese, whey } \\
\text { powder, whey protein concentrate, } \\
\text { demineralised whey powder, skim } \\
\text { milk powder, creams and ice cream }\end{array}$ & General plant effluent & Current work \\
\hline
\end{tabular}


Table 3: Characteristics of the waste streams collected for the CTL study (data extracted from (Baskaran et al., 2007)).

\begin{tabular}{|c|c|c|c|c|c|c|}
\hline Characteristic & Unit & $\begin{array}{c}\text { Spent caustic } \\
\text { sample }\end{array}$ & Salty whey & $\begin{array}{c}\text { NF permeate from } \\
\text { salty whey }\end{array}$ & $\begin{array}{c}\text { lon exchanger } \\
\text { regeneration } \\
\text { solution }\end{array}$ & $\begin{array}{c}\text { Secondary treated } \\
\text { effluent }\end{array}$ \\
\hline Turbidity & NTU & 12 & 1,700 & 0.6 & 38 & 31.3 \\
\hline COD & {$[\mathrm{mg} / \mathrm{L}]$} & 590 & 29,330 & 6,700 & 1,240 & 141 \\
\hline Conductivity & $\mu \mathrm{S} / \mathrm{cm}$ & 22,100 & 43,500 & 86,600 & 25,700 & 5,170 \\
\hline TDS & {$[\mathrm{mg} / \mathrm{L}]$} & 7,650 & 47,930 & 76,680 & 23,800 & 3,626 \\
\hline Sodium & {$[\mathrm{mg} / \mathrm{L}]$} & 2,940 & 12,620 & 32,650 & 6,840 & \\
\hline
\end{tabular}

\# The NF permeate from salty whey had been concentrated by evaporation - high conductivity was observed. 


\section{Brine management}

High salinity waste streams can be stored for long periods in solar evaporation ponds. This practice can result in land degradation issues, however, should the pond liner be compromised.(Aral and Sleigh, 2007) While evaporation ponds are often placed within land owned by the operating dairy companies, environmental impacts in regards to land degradation, odour and dust are of concern to environmental regulators. The construction of further evaporation ponds has therefore been barred in some areas of New South Wales and Queensland, Australia(Fell, 2014).

In other industries, deep well injection into an appropriate subsurface geological formation, usually a non-potable aquifer, is often used as a permanent method of disposal. This is only feasible in specific geological locations, however, and can be very costly due to the extensive operation and maintenance costs and pre-treatment for suspended solids removal (Heins, Patent Publication Number US 7681643 B2, 2010; Jordahl, 2006). Disposal to sea is another option in coastal regions but also requires the brine to be of suitable quality. In recent years, zero liquid discharge (ZLD) has been studied intensively to utilise a combination of desalination processes to produce fresh water of high purity with no discharge of liquid waste. In this case, the brine is completely evaporated by thermo-mechanical means to a solid residue (or salt cake) for proper disposal.

For plants that are discharging wastewater to the sewer, the level of salinity in the trade waste becomes crucial. In Australia, financial charges are typically imposed upon trade waste based on both wastewater volume and on the concentration of contaminants, such as total solids, total suspended solids, BOD, sodium, nitrogen and phosphorous(East Gippsland Water Victoria Australia, 2017; Gippsland Water Victoria Australia, 2017; Goulburn Valley Water Victoria Australia, 2017; SA Water Australia, 2017; Sydney Water New South Wales Australia; Water corporation (Australia), 2017). In the Goulburn Valley, a dairy farming region of northern Victoria in Australia, typical charges are $72 \pm$ 15 Australian cents per kL of wastewater and $95 \pm 23$ Australian cents per kg of sodium discharged (Goulburn Valley Water Victoria Australia, 2017). Figure 4 compares the effect of removing sodium 
from typical process streams to that of reducing the total volume of these streams. It can be seen that for a low salinity effluent, such as secondary treated effluent (763 mg/L sodium), there is little difference in savings between volume reduction and sodium removal. As the salt concentration increases to $12.6 \mathrm{~g} / \mathrm{L}$ sodium in salty whey, a reduction of $90 \%$ of wastewater volume leads to only $<20 \%$ saving in trade waste charges. A removal of $20 \%$ of the sodium can produce a similar $20 \%$ saving in trade waste charges. This reflects the high costs imposed for sodium discharge, suggesting that management strategies should focus more on salt minimisation and removal rather than water recovery.

It is anticipated that local water authorities will impose heavier penalties for sodium disposal in the future (City West Water Victoria Australia, 2017). The companies surveyed in this work have observed that any increase in the salinity level in their effluent will also impose extra load to the onsite water treatment facilities that also incur additional treatment costs. This influences current and future management strategies in the dairy manufacturing industry and makes waste reduction and salt recovery or removal of vital interest. 


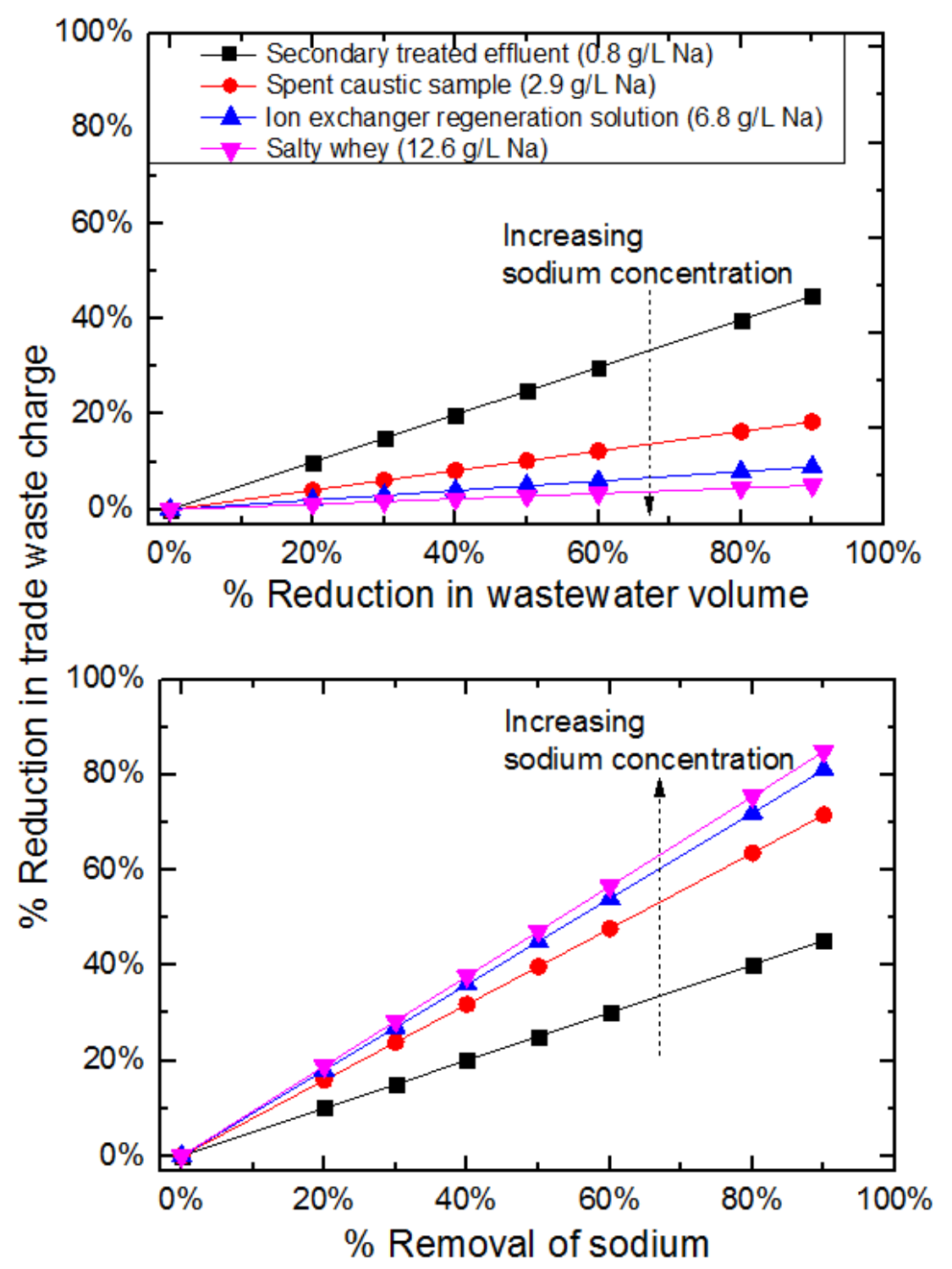

Figure 4: Estimated reduction of trade waste charges for different salty streams listed in Table 3 as a function of the degree of removal of water (a) and sodium (b). Calculated based on $0.2 \mathrm{AUD} / \mathrm{kL}$ of wastewater and 0.95 AUD/kg sodium in wastewater. (AUD: Australian Dollar)

\section{Conclusions}

Salty waste streams are generated in dairy processing plants through Australia. These streams originate from dairy processing operations include: NF whey demineralisation waste, electrodialysis, ion exchange, and chromatography brines and CIP wastewater.

An industry survey was conducted to the Australian dairy industry to review the current management strategies for salty waste streams. These streams are usually diluted with other low salinity in-plant 
effluents and treated within onsite or offsite wastewater treatment facilities. When the volume of these streams is significant and can jeopardise the operation of the conventional treatment processes, high salinity waste streams are discharged separately to evaporation ponds. Environmental concerns arise from both approaches due to the high level of organic load and salinity, causing increasing costs in wastewater treatment and brine management or disposal, an increase in agricultural water usage, as well as the potential for degradation of local land. Management strategies for these waste streams are restricted by increasingly strict environmental regulations. Appropriate actions must be taken to avoid, minimize, reuse and recover these high salinity streams, hence reducing their environmental impact and potentially providing new opportunities for the dairy industry.

It is apparent that current management strategies cannot provide a permanent solution to the environmental concerns and the increasing regulatory requirements associated with salty waste streams. Existing dairy plants are restricted by both economic constraints and by their ability to provide the requisite power for employing energy intensive processes. Even if salt based by-products or value-added dairy products can be produced, the economic case needs to be justified by the capital investment, volume of production and market demand. These streams are multicomponent systems containing inorganic and organic species. It is likely that a systematic treatment module that involves a number of desalination technologies is required. Future work should consider technologies that are able to reduce salty waste stream volume and/or recover valuable products within the waste stream or at the point of origin of the waste stream, minimizing the impact of salinity in the final effluent. 


\section{Acknowledgements}

This research was supported under Australian Research Council's Industrial Transformation Research Program (ITRP) funding scheme (project number IH120100005). The ARC Dairy Innovation Hub is a collaboration between The University of Melbourne, The University of Queensland and Dairy Innovation Australia Ltd.

The authors would like to thank all the participating dairy companies in Australia for their generous support to the survey study. Helpful discussions with Dr David Barr and Mr Neil van Buuren are greatly appreciated.

\section{References}

Andrade, L.H., Mendes, F.D.S., Espindola, J.C., Amaral, M.C.S., 2014. Nanofiltration as tertiary treatment for the reuse of dairy wastewater treated by membrane bioreactor. Sep. Purif. Technol. 126, 21-29.

Aral, H., Sleigh, R., 2007. Closing the Loop: An holistic approach to the management of dairy processor waste stream-Salt Recovery Strategies for New Value-Added Salt Products, Part Two. Department of Environment and Primary Industries, Queenscliff, Australia.

Aral, H., Sleigh, R., Simons, L., 2007. Closing the Loop: An holistic approach to the management of dairy processor waste streams-Salt Recovery Strategies for New Value-addd Salt products, Part One. Department of Environment and Primary Industries, Queenscliff, Australia.

Baskaran, K.B., Jamil, K., Farago, L., Jeyaseelan, S., Wang, M., 2007. Closing the Loop: An holistic approach to the management of dairy processor waste streams-Evaluation of Technologies for Removal of Salts from Wastewater Streams in Dairy Processing Industries, Final Milestone Report. Department of Priminary Industries, Queenscliff, Australia.

Benitez, R.M., Ortero, G.M., 2012. Whey : types, composition and health implications, Benitez, R.M., Ortero, G.M. (Eds.), Hauppauge, N.Y. : Nova Science Publishers.

Blaschek, K.M., Wendorff, W.L., Rankin, S.A., 2007. Survey of Salty and Sweet Whey Composition from Various Cheese Plants in Wisconsin. J. Dairy Sci. 90, 2029-2034.

Bylund, G., Hellman, M., 2015. Dairy processing handbook. Tetra Pak Processing Systems, Lund, Sweden.

City West Water Victoria Australia, 2017. Trade Waste - Sodium and Salinity.

Dairy Australia, 2016. Australian Dairy Industry In Focus 2016. Dairy Australia Limited.

Danalewich, J.R., Papagiannis, T.G., Belyea, R.L., Tumbleson, M.E., Raskin, L., 1998. Characterization of dairy waste streams, current treatment practices, and potential for biological nutrient removal. Water Res. 32, 3555-3568.

Daufin, G., Escudier, J.P., Carrère, H., Bérot, S., Fillaudeau, L., Decloux, M., 2001. Recent and Emerging Applications of Membrane Processes in the Food and Dairy Industry. Food Bioprod. Process. 79, 89-102.

de Jong, P., 2013. Sustainable Dairy Production. Chicester : Wiley, 2013.

de Wit, J.N., 2001. Lecturer's Handbook on whey and whey products, 1st ed. European Whey Products Association (EWPA), Belgium. 
Department of the Environment Australia, 1999. National Water Quality Management Strategy Effluent management guidelines for dairy processing in Australia.

Dresch, M., Daufin, G., Chaufer, B., 2001. Integrated membrane regeneration process for dairy cleaning-in-place. Sep. Purif. Technol. 22-23, 181-191.

Durham, R.J., Hourigan, J.A., 2009. Waste management and co-product recovery in dairy processing, in: Waldron, K. (Ed.), Handbook of Waste Management and Co-Product Recovery in Food Processing, Volume 1. Woodhead Publishing Limited and CRC Press LLC, pp. 332-387.

East Gippsland Water Victoria Australia, 2017. Tariffs, Charges \& Pricing Principles 1 July 2017-30 June 2018.

Eide, M.H., Homleid, J.P., Mattsson, B., 2003. Life cycle assessment (LCA) of cleaning-in-place processes in dairies. LWT - Food Sci. Technol. 36, 303-314.

Farrell, R., Maginnis, H., 2016. Dairy and Products Semi-annual (Australia). United States Department of Agriculture, Washington, DC.

Fell, C., 2014. Discussion Paper for Office of NSW Chief Scientist and Engineer: Water Treatment And Coal Seam Gas. Fell Consulting Pty Ltd.

Foreign Agricultural Service, United States Department of Agriculture (USDA), 2013. Dairy: World Markets and Trade.

Gernigon, G., Schuck, P., Jeantet, R., Burling, H., 2011. Whey processing; demineralization. Encyclopedia of dairy sciences, 2nd Ed. Academic, San Diego, 738-743.

Gippsland Water Victoria Australia, 2017. Commercial trade waste.

Goulburn Valley Region Water Corporation, 2012. Statement of approved acceptance criteria for trade waste discharge.

Goulburn Valley Water Victoria Australia, 2017. 2017-2018 Tariff schedule.

Greiter, M., Novalin, S., Wendland, M., Kulbe, K.-D., Fischer, J., 2002. Desalination of whey by electrodialysis and ion exchange resins: analysis of both processes with regard to sustainability by calculating their cumulative energy demand. J. Membr. Sci. 210, 91-102.

Harper, W.J., Blaisdell, J.L., Grosshopf, J., 1972. Dairy food plant wastes and waste treatment practices. U.S. Environmental Protection Agency, Washington, DC.

Heins, W.F., Patent Number US 7681643 B2, 2010. Treatment of brines for deep well injection. GE Ionics, Inc.

Henck, M., 1995. Recycling of used caustic cleaning solutions in the dairy industry by cross-flow filtration. Bulletin-International Dairy Federation, 175-183.

Jordahl, J., 2006. Beneficial and Nontraditional Uses of Concentrate [Project \#2971]. Water Research Foundation.

Kapoor, R., Metzger, L.E., 2004. Evaluation of Salt Whey as an Ingredient in Processed Cheese. J. Dairy Sci. 87, 1143-1150.

Kumar, P., Sharma, N., Ranjan, R., Kumar, S., Bhat, Z., Jeong, D.K., 2013. Perspective of membrane technology in dairy industry: a review. Asian-Australas. J. Anim. Sci. 26, 1347.

Merin, U., Gesan-Guiziou, G., Boyaval, E., Daufin, G., 2002. Cleaning-in-place in the dairy industry: criteria for reuse of caustic $(\mathrm{NaOH})$ solutions. Lait 82, 357-366.

Nair, S.S., Mistry, V.V., Nauth, K.R., 2004. Reduction of Salt (NaCl) Losses During the Manufacture of Cheddar Cheese. J. Dairy Sci. 87, 2831-2838.

Nguyen, M., Reynolds, N., Vigneswaran, S., 2003. By-product recovery from cottage cheese production by nanofiltration. J. Clean. Prod. 11, 803-807.

OECD, 2016. Organization for Economic Cooperation and Development Food and Agriculture Organisation of the United Nations, Agricultural Outlook 2016-2025,.

Okawa, T., Shimada, M., Ushida, Y., Seki, N., Watai, N., Ohnishi, M., Tamura, Y., Ito, A., 2015. Demineralisation of whey by a combination of nanofiltration and anion - exchange treatment: a preliminary study. Int. J. Dairy Tech. 68, 478-485. 
Pesta, G., Meyer-Pittroff, R., Russ, W., 2007. Uitilization of Whey, in: Oreopoulou, V., Russ, W. (Eds.), Utilization of by-products and treatment of waste in the food industry. New York : Springer, pp. 193-207.

Prazeres, A.R., Carvalho, F., Rivas, J., 2012. Cheese whey management: A review. J. Environ. Mgmt. $110,48-68$.

Räsänen, E., Nyström, M., Sahlstein, J., Tossavainen, O., 2002. Purification and regeneration of diluted caustic and acidic washing solutions by membrane filtration. Desalination 149, 185-190.

Renner, E., Abd El-Salam, M.H., 1991. Application of ultrafiltration in the dairy industry. Elsevier Applied Science, London; New York.

SA Water Australia, 2017. Trade Waste Fees and Charges 2017-2018.

Siso, M.G., 1996. The biotechnological utilization of cheese whey: a review. Bioresource Technol. 57, 1-11.

Sleigh, R.W., Aral, H., Simons, L., Santangelo, R., et al., 2006. Sustainable management of salty waste streams from cheese manufacture. Aust. J. Dairy Technol. 61, 193-195.

South Gippsland Water, 2013. Trade waste statement of approved acceptance criteria information. South Gippsland Water.

Sydney Water New South Wales Australia, Trade waste fees and charges.

Tawfik, A., Sobhey, M., Badawy, M., 2008. Treatment of a combined dairy and domestic wastewater in an up-flow anaerobic sludge blanket (UASB) reactor followed by activated sludge (AS system). Desalination 227, 167-177.

Trebler, H.A., Ernsberger, R.P., Roland, C.T., Siebert, C.L., 1938. Dairy Waste Elimination and Sewage Disposal [with Discussion]. Sewage Works Journal 10, 868-889.

United Nations Environment Programme (UNEP), 2000. Cleaner Production Assessment in Dairy Processing. United Nations Environment Programme and Danish Environmental Protection Agency, prepared by COWI Consulting Engineers and Planners, Bosworth M E, Hummelmose B, and Christiansen K, Denmark.

Venkatraman, K., Achi, M., 2004. To eliminate the disposal of salty whey from a dairy industry into the sewer in an environmental, social and economical way - a case study from dairy farmers, Toowoomba, Queensland, Australia. Int. J. Env. Tech. Mgmt. 4, 365-374.

Verheyen, V., Cruickshank, A., Wild, K., Heaven, M.W., McGee, R., Watkins, M., Nash, D., 2009. Soluble, semivolatile phenol and nitrogen compounds in milk-processing wastewaters. J. Dairy Sci. 92, 3484-3493.

Verheyen, V., Cruickshank, A., Wild, K., Heaven, M.W., McGee, R., Watkins, M., Nash, D., 2011. Characterization of organic particulates present in milk factory process waters used for reuse along with aerobically digested effluent wastewater. Bioresource Technol. 102, 2118-2125.

Water corporation (Australia), 2017. Trade waste charges.

Watkins, M., Nash, D., 2010. Dairy Factory Wastewaters, Their Use on Land and Possible Environmental Impacts: A Mini Review. Open Agric. J. 4.

Western Water, 2011. Acceptance criteria for trade waste discharge to the sewerage system.

Wilkinson, K., Brooks, R., Balmer, C., Halliwell, D., Palmowski, L., Issa, J., Jeyaseelan, S., Truong, t., Wilson, H., Meehan, N., Baskaran, K.B., 2004. Closing the loop: Survey of Dairy Factory Solid and Liquid Waste Management Practices - Final Report.

Wilkinson, K.G., 2007. Characterisation of selected dairy processing waste streams from Victoria, Australia. Aust. J. Dairy Tech. 62, 159.

Yarra Valley Water Victoria Australia, 2014. Trade waste approved acceptance criteria. 


\section{Figure Captions}

Figure 1: A typical approach for dairy processing waste management in Australia and New Zealand (Danalewich et al., 1998; Department of the Environment Australia, 1999; Sleigh et al., 2006; United Nations Environment Programme (UNEP), 2000; Watkins and Nash, 2010; Wilkinson, 2007). (* Wastewater treatments include various arrangements of standard technologies, which are not shown in detail; ** Sludge and biosolids are generated from biological treatment and wastewater separation processes (such as Dissolved Air Flotation.)

Figure 2: World dairy projections (2016-2025). Data from the Organisation for Economic Cooperation and Development (OECD 2016). (kt pw: kilotonne per week)

Figure 3: A typical cheese making process, the possible process alternatives for whey utilization and the salty waste streams generated (information extracted from (Bylund and Hellman, 2015; de Jong, 2013; de Wit, 2001; Durham and Hourigan, 2009; Pesta et al., 2007; Prazeres et al., 2012; Renner and Abd El-Salam, 1991; Siso, 1996; Venkatraman and Achi, 2004)).

Figure 4: Estimated reduction of trade waste charges for different salty streams listed in Table 3 as a function of the degree of removal of water (a) and sodium (b). Calculated based on $0.2 \mathrm{AUD} / \mathrm{kL}$ of wastewater and 0.95 AUD/kg sodium in wastewater. (AUD: Australian Dollar) 


\section{Supplementary Materials}

for

\section{A Review of Salty Waste Stream Management in the Australian Dairy Industry}

G. Q. Chen ${ }^{1}$, S. Talebi ${ }^{1}$, S. L. Gras ${ }^{1,2}$, M. Weeks ${ }^{3}$, S. E. Kentish ${ }^{1 *}$

${ }^{1}$ The ARC Dairy Innovation Hub, Department of Chemical Engineering, University of Melbourne, Victoria 3010, Australia.

2 The Bio21 Molecular Science and Biotechnology Institute, The University of Melbourne, Victoria 3010, Australia

${ }^{3}$ The Dairy Innovation Australia Ltd., Werribee, VIC 3030, Australia

*Corresponding Author

Prof S. Kentish

Tel: +61383446682

Fax: +61 383444153

E-mail address: sandraek@unimelb.edu.au 
This file contains supplementary information to summarise the physical and chemical characteristics of wastewater (Tables S1 and S2) originating from a variety of dairy processing plants that are tabulated in Table 2.

Table S3 contains the typical composition of sweet whey, acid whey and salty whey. 
Table S1: Physical and chemical characteristics of wastewater originating from a variety of dairy processing plants. References and further information are presented in Table 2.

\begin{tabular}{|c|c|c|c|c|c|c|c|c|c|c|c|c|c|c|c|c|c|c|c|c|c|c|c|}
\hline \multirow[t]{3}{*}{$\begin{array}{c}\text { Case } \\
\text { ID }\end{array}$} & \multirow[t]{3}{*}{ Plant } & \multirow[t]{3}{*}{ Waste Type } & \multirow{2}{*}{\multicolumn{3}{|c|}{$\begin{array}{l}\text { Waste Volume } \\
\text { Coefficient } \\
\text { L/L milk processed }\end{array}$}} & \multirow{2}{*}{\multicolumn{3}{|c|}{$B O D$ or $B O D_{5}$}} & \multicolumn{3}{|c|}{$C O D$} & \multicolumn{3}{|c|}{$\begin{array}{c}B O D_{5} / C O D \text { or } \\
B O D / C O D\end{array}$} & \multicolumn{3}{|c|}{$p H$} & \multicolumn{3}{|c|}{ Conductivity } & \multicolumn{3}{|c|}{$T S$} \\
\hline & & & & & & & & & & $\mathrm{mg} / \mathrm{l}$ & & & & & & & & & $\mu \mathrm{S} / \mathrm{cm}$ & & & $\mathrm{mg} / \mathrm{l}$ & \\
\hline & & & Min & $\max$ & mean & $\min$ & $\max$ & mean & $\min$ & $\max$ & mean & $\min$ & $\max$ & mean & $\min$ & $\max$ & \begin{tabular}{|l|} 
mean \\
\end{tabular} & $\min$ & $\max$ & mean & $\min$ & $\max$ & mean \\
\hline 1 & $\begin{array}{l}15 \text { plants, Primary product: mostly } \\
\text { hard/semi-hard cheese }\end{array}$ & $\begin{array}{l}\text { Composite } \\
\text { wastewater samples }\end{array}$ & 0.35 & 2.60 & 1.43 & 565 & 5,722 & 1,856 & 785 & 7,619 & 2,855 & 0 & 0.78 & 0.63 & 6.2 & 11.3 & 8.4 & & & & 1,837 & 14,205 & 2,790 \\
\hline 2 & $\begin{array}{l}24 \text { production sites, products } \\
\text { include milk, cream, butter, cheese, } \\
\text { powder, ice cream, dairy dessert }\end{array}$ & Wastewater & & & 1.55 & 5 & 6,420 & 2,009 & 50 & 11,000 & 3,391 & & & 0.59 & 5 & 12.5 & 9 & & & & & & \\
\hline 3 & $\begin{array}{l}\text { Mozzarella cheese, whey powder, } \\
\text { butter and vein cheese (18:3:8:0.08) }\end{array}$ & $\begin{array}{l}\text { A mixture of } \\
\text { discarded whey } \\
\text { and wash water }\end{array}$ & & & & & & 2,150 & & & 3,200 & & & 0.67 & & & 6.7 & & & & & & 2,300 \\
\hline 4 & $\begin{array}{l}\text { Arab Dairy Factory (Cheese } \\
\text { manufacturing) }\end{array}$ & $\begin{array}{l}\text { End of pipe } \\
\text { effluent, mix of } \\
\text { dairy and domestic } \\
\text { water ( } 7 \text { to } 3 \text { ) } \\
\end{array}$ & & & & & & 1,941 & & & 3,383 & & & 0.57 & & & 7.9 & & & & & & \\
\hline 5 & Cheese & Not-specified & & & & & & 2,800 & & & & & & & & & 6.9 & & & 3,500 & & & \\
\hline 6 & Cheese/milk powder & Effluent & & & & & & 1,500 & & & & & & & & & 10.6 & & & 2,600 & & & \\
\hline 7 & $\begin{array}{l}\text { Small-scale specialty farm cheese } \\
\text { manufacturers }\end{array}$ & $\begin{array}{l}\text { Washdown } \\
\text { wastewater }\end{array}$ & & & & 100 & 2,000 & 1,500 & 1,500 & 3,500 & 2,400 & & & 0.63 & 6.0 & 9.0 & 7.0 & & & & 1,500 & 2,500 & 1,750 \\
\hline 8 & $\begin{array}{l}\text { Customized fresh and frozen dairy } \\
\text { ingredients }\end{array}$ & $\begin{array}{l}\text { Dirty stream - } \\
\text { effluent before any } \\
\text { treatment }\end{array}$ & & & & 700 & 1,700 & & & & & & & & 8.0 & 12.0 & & & & 2,600 & & & \\
\hline 9 & $\begin{array}{l}\text { Customized fresh and frozen dairy } \\
\text { ingredients }\end{array}$ & $\begin{array}{l}\text { Effluent from the } \\
\text { aerobic bioreactor }\end{array}$ & & & & & & & & & & & & & & & 8.44 & & & 1,876 & & & 1,310 \\
\hline 10 & $\begin{array}{l}\text { UHT milk, yogurt, cheese, cottage } \\
\text { cheese and petit Suisse }\end{array}$ & $\begin{array}{l}\text { Post sieving and } \\
\text { induced air } \\
\text { flotation (IAF) }\end{array}$ & & & & & & 1,120 & & & 2,938 & & & 0.38 & & & & & & & & & 3.36 \\
\hline 11 & $\begin{array}{l}\text { (hard and soft) cheese, whey } \\
\text { powder, whey protein concentrate, } \\
\text { demineralised whey powder, skim } \\
\text { milk powder, creams and ice cream }\end{array}$ & Wastewater & 0.8 & 3.8 & 1.8 & & & & & & & & & & 4 & 12.5 & & 1,500 & 9,500 & 3,000 & & & \\
\hline
\end{tabular}


Table S2: Physical and chemical characteristics of wastewater originating from a variety of dairy processing plants. References and further information are presented in Table 2.

\begin{tabular}{|c|c|c|c|c|c|c|c|c|c|c|c|c|c|c|c|c|c|c|c|c|c|c|c|}
\hline \multirow{3}{*}{$\begin{array}{l}\text { Case } \\
\text { ID }\end{array}$} & \multirow[t]{3}{*}{ Plant } & \multirow[t]{3}{*}{ Waste Type } & \multicolumn{3}{|c|}{$T K N / T N$} & \multicolumn{3}{|c|}{ TP/phosphorous } & \multicolumn{3}{|c|}{ TSS } & \multicolumn{3}{|c|}{ VSS } & \multicolumn{3}{|c|}{ TDS } & \multicolumn{3}{|c|}{ VS } & \multicolumn{3}{|c|}{$\mathrm{Na}$} \\
\hline & & & \multicolumn{3}{|c|}{$\mathrm{mg} / \mathrm{l}$} & \multicolumn{3}{|c|}{$\mathrm{mg} / \mathrm{l}$} & \multicolumn{3}{|c|}{$\mathrm{mg} / \mathrm{l}$} & \multicolumn{3}{|c|}{$\mathrm{mg} / \mathrm{l}$} & \multicolumn{3}{|c|}{$\mathrm{mg} / \mathrm{l}$} & \multicolumn{3}{|c|}{$\mathrm{mg} / \mathrm{l}$} & \multicolumn{3}{|c|}{$\mathrm{mg} / \mathrm{l}$} \\
\hline & & & $\min$ & $\max$ & mean & $\min$ & $\max$ & mean & $\min$ & $\max$ & mean & $\min$ & $\max$ & mean & $\min$ & $\max$ & mean & $\min$ & $\max$ & mean & $\min$ & $\max$ & mean \\
\hline 1 & $\begin{array}{l}15 \text { plants, Primary product: mostly } \\
\text { hard/semi-hard cheese }\end{array}$ & $\begin{array}{l}\text { Composite wastewater } \\
\text { samples }\end{array}$ & 14 & 140 & 91.4 & 181 & 29 & 71 & 326 & 3,560 & 976 & 225 & 1,936 & 703 & & & $1,814^{\#}$ & 562 & 11,034 & 2,790 & 263 & 1,265 & 544 \\
\hline 2 & $\begin{array}{l}24 \text { production sites, products } \\
\text { include milk, cream, butter, } \\
\text { cheese, powder, ice cream, dairy } \\
\text { dessert }\end{array}$ & Wastewater & 5 & 460 & 88 & 0.02 & 160 & 40 & 10 & 2,500 & 760 & & & & 800 & 7,000 & 2,680 & & & & 130 & 1,000 & 532 \\
\hline 3 & $\begin{array}{l}\text { Mozzarella cheese, whey powder, } \\
\text { butter and vein cheese } \\
(18: 3: 8: 0.08)\end{array}$ & $\begin{array}{l}\text { A mixture of discarded } \\
\text { whey and wash water }\end{array}$ & & & & & & & & & 600 & & & & & & $1,700^{\#}$ & & & 690 & & & \\
\hline 4 & $\begin{array}{l}\text { Arab Dairy Factory (Cheese } \\
\text { manufacturing) }\end{array}$ & $\begin{array}{l}\text { End of pipe effluent, mix } \\
\text { of dairy and domestic } \\
\text { water (7 to } 3 \text { ) }\end{array}$ & & & 51 & & & 22 & & & 831 & & & 746 & & & $564^{\#}$ & & & & & & \\
\hline 5 & Cheese & Not-specified & & & 150 & & & 42 & & & & & & & & & & & & & & & \\
\hline 6 & Cheese/milk powder & Effluent & & & 0.01 & & & 35 & & & & & & & & & & & & & & & \\
\hline 7 & $\begin{array}{l}\text { Small-scale specialty farm cheese } \\
\text { manufacturers }\end{array}$ & Washdown wastewater & 50 & 150 & 105 & & & & 500 & 2,000 & 1,000 & & & & & & $750^{\#}$ & & & & & & \\
\hline 8 & $\begin{array}{l}\text { Customized fresh and frozen dairy } \\
\text { ingredients }\end{array}$ & $\begin{array}{l}\text { Dirty stream - effluent } \\
\text { before any treatment }\end{array}$ & 50 & 70 & & & & 10 & & & & & & & & & & & & & & & \\
\hline 9 & $\begin{array}{l}\text { Customized fresh and frozen dairy } \\
\text { ingredients }\end{array}$ & $\begin{array}{l}\text { Effluent from the aerobic } \\
\text { bioreactor }\end{array}$ & & & & & & & & & 700 & & & & & & & & & & & & \\
\hline 10 & $\begin{array}{l}\text { UHT milk, yogurt, cheese, cottage } \\
\text { cheese and petit suisse }\end{array}$ & $\begin{array}{l}\text { Post sieving and induced } \\
\text { air flotation (IAF) }\end{array}$ & & & 49.8 & & & 36.3 & & & & & & & & & & & & 1.84 & & & \\
\hline 11 & $\begin{array}{l}\text { (hard and soft) cheese, whey } \\
\text { powder, whey protein concentrate, } \\
\text { demineralised whey powder, skim } \\
\text { milk powder, creams and ice cream }\end{array}$ & & & & & & & 40 & & & & & & & & & & & & & & & 600 \\
\hline
\end{tabular}


Table S3: Typical composition of sweet whey, acid whey and salty whey.

\begin{tabular}{|c|c|c|c|c|c|c|c|c|c|c|c|c|c|c|c|c|c|}
\hline \multirow{4}{*}{ Reference } & \multirow[b]{2}{*}{ Unit } & \multicolumn{5}{|c|}{ Sweet Whey } & \multicolumn{4}{|c|}{ Acid whey } & \multicolumn{7}{|c|}{ Salty Whey } \\
\hline & & \multirow{3}{*}{$\begin{array}{c}\mathrm{U} / \mathrm{S}^{\#} \\
\text { (Benitez } \\
\text { and } \\
\text { Ortero, } \\
2012 \text { ) }\end{array}$} & \multirow{3}{*}{$\begin{array}{c}\mathrm{U} / \mathrm{S}^{\#} \\
\text { (Bylund } \\
\text { and } \\
\text { Hellman, } \\
\text { 2015) }\end{array}$} & \multirow{3}{*}{$\begin{array}{l}\text { (Blaschek } \\
\text { et al., } \\
2007 \text { ) }\end{array}$} & Cheddar & Cheddar & $\mathrm{U} / \mathrm{S}^{\#}$ & Cottage & Casein & Lactic & Mozzarella & Colby & & heddar & & Cheddar & Cheddar \\
\hline & 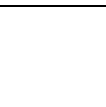 & & & & \multirow{2}{*}{$\begin{array}{l}\text { (Nair et } \\
\text { al., 2004) }\end{array}$} & \multirow{2}{*}{$\begin{array}{c}\text { (Durham } \\
\text { and } \\
\text { Hourigan, } \\
\text { 2009) }\end{array}$} & \multirow{2}{*}{$\begin{array}{l}\text { (Benitez } \\
\text { and } \\
\text { Ortero, } \\
\text { 2012) }\end{array}$} & \multirow{2}{*}{$\begin{array}{l}\text { (Nguyen } \\
\text { et al., } \\
\text { 2003) }\end{array}$} & \multirow{2}{*}{$\begin{array}{l}\text { (Bylund } \\
\text { and } \\
\text { Hellman, } \\
\text { 2015) }\end{array}$} & \multirow{2}{*}{$\begin{array}{l}\text { (Durham } \\
\text { and } \\
\text { Hourigan, } \\
\text { 2009) }\end{array}$} & \multirow{2}{*}{$\begin{array}{l}\text { (Blaschek } \\
\text { et al., 2007) }\end{array}$} & \multirow{2}{*}{$\begin{array}{l}\text { (Blaschek } \\
\text { et al., } \\
\text { 2007) }\end{array}$} & \multicolumn{3}{|c|}{$\begin{array}{l}\text { (Blaschek et al., } \\
\text { 2007) }\end{array}$} & \multirow{2}{*}{$\begin{array}{l}\text { (Kapoor } \\
\text { and } \\
\text { Metzger, } \\
\text { 2004) }\end{array}$} & \multirow{2}{*}{$\begin{array}{c}\text { (Nair et } \\
\text { al., } \\
\text { 2004) }\end{array}$} \\
\hline & - & & & & & & & & & & & & $\min$ & $\max$ & avg & & \\
\hline $\mathrm{pH}$ & - & $5.9-6.3$ & & & & 6.1 & $4.6-4.6$ & 4.54 & & 4 & & & & & & & \\
\hline Total solids & $\%$ & 6.4 & 6.4 & 6.6 & 7.74 & 6.6 & 6.2 & 6.23 & 6.5 & 6 & 8.6 & 9.8 & 6.1 & 24.1 & 12.4 & 17.8 & 16.1 \\
\hline Fat & $\%$ & 0.5 & 0.05 & 0.2 & 0.27 & 0.06 & 0.04 & 0.38 & 0.04 & 0.003 & 0.6 & 0.8 & 0.2 & 1.1 & 0.6 & 1.69 & 1.34 \\
\hline Lactose & $\%$ & 4.6 & 4.8 & & & 4.8 & 4 & 4.8 & 4.9 & 3.9 & & & & & & & \\
\hline Lactic acid & $\%$ & 0.05 & 0.05 & & & 0.13 & 0.8 & 0.55 & 0.4 & 0.6 & & & & & & & \\
\hline $\begin{array}{l}\text { Minerals } \\
\text { (ash) }\end{array}$ & $\%$ & 0.5 & 0.5 & 0.2 & 0.5 & 0.59 & 0.8 & 0.33 & 0.9 & 0.72 & 2.5 & 4 & 2.6 & 18.9 & 6.9 & 8.71 & 7.84 \\
\hline Calcium & $\%$ & & 0.043 & & & 0.043 & & 0.0766 & 0.12 & 0.114 & & & & & & & \\
\hline Phosphorus & $\%$ & & 0.04 & & & 0.044 & & & 0.065 & 0.09 & & & & & & & \\
\hline Sodium & $\%$ & & 0.05 & & & 0.043 & & 0.0609 & 0.05 & 0.04 & & & & & & & \\
\hline Potassium & $\%$ & & 0.16 & & & 0.143 & & 0.1818 & 0.16 & 0.153 & & & & & & & \\
\hline Chloride & $\%$ & & 0.11 & & & 0.097 & & & 0.11 & 0.091 & & & & & & & \\
\hline Magnesium & $\%$ & & & & & & & 0.0088 & & & & & & & & & \\
\hline $\begin{array}{l}\text { Total } \\
\text { Nitrogen }\end{array}$ & $\%$ & 0.8 & & & & & 0.7 & & & & & & & & & & \\
\hline True Proteins & $\%$ & & 0.55 & 0.8 & 0.93 & & & 0.66 & 0.55 & & 0.7 & 0.7 & 0.3 & 1.0 & 0.6 & & 1.23 \\
\hline
\end{tabular}

\# U/S: Unspecified 